\title{
Distance Education at the Grassroots and Assessment Procedures. The Case of the University of Cape Coast, Ghana
}

\author{
Kwao Alex \\ Department of Basic Education, University of Cape Coast, Ghana \\ Email: Alexkn2003@yahoo.com
}

How to cite this paper: Alex, K. (2019). Distance Education at the Grassroots and Assessment Procedures. The Case of the University of Cape Coast, Ghana. Creative Education, 10, 78-96.

https://doi.org/10.4236/ce.2019.101006

Received: November 6, 2018

Accepted: January 12, 2019

Published: January 15, 2019

Copyright $\odot 2019$ by author(s) and Scientific Research Publishing Inc. This work is licensed under the Creative Commons Attribution-NonCommercial International License (CC BY-NC 4.0). http://creativecommons.org/licenses/by-nc/4.0/

\begin{abstract}
Distance education is an innovative learning experience which focuses on learning technology with the aim of creating human capital by using delivery of lessons from highly accredited source to the learner. At the University of Cape Coast in Ghana, individuals from diverse backgrounds and organizations embark on distance learning who under normal circumstances would not have had access to attend classes in the mainstream. The compelling need to determine their success in various centres is determined by effective assessment procedures and programme evaluation. This depends on types, structures, tools, mode of delivery and assessment records. This paper therefore examines the academic underpinnings of what precisely occurs at the University of Cape Coast. The paper instigates an inquiry to draw attention to learning outcomes of the "new" academic environment which stakeholders are benefitting from. The investigation was a case study from selected centres of the Eastern region. It adopted the mixed approach with sample selection which involved 50 students, 30 course tutors and 5 course coordinators. Semi-structured interview and group discussion were used as validation tools. Analytical processes were through sequencing and concurrent procedures using descriptive statistics and discursive method as basis for generating data. Respondents claimed that assessment procedures were superb. However, both students and course tutors complained about continuous assessment component of Teacher Made Test which is entirely ignored. The recommendation was to adopt well defined assessment and evaluation strategies.
\end{abstract}

\section{Keywords}

Assessment Procedures, Distance Education, Grassroots, Learning Technology 


\section{Introduction}

Distance education otherwise distance learning is a field of study that focuses on modern scientific way of learning by the use of methods and technology in order to reach out to people who may not have had access to attend regular or mainstream classes. Across the globe today, distance learning has been instituted as one of the best practices from a remote source to the learner. This indeed can be organized within a complex or simple environment which also suggests grassroots participation of learning experiences. Other institutions and organizations have embarked on distance education to reduce capacity constraints on campuses and equal access to quality education.

The content and structure of every programme depend on individual needs, institutional and societal needs, to suggest, needs are based on proximate goals of individuals, mediate goals of institutions and ultimate goals of government. There is therefore the compelling need to determine their successes through effective assessment and programme evaluation. Considering the potential benefits distance education is gaining, it appears very little has been written and discussed about the effectiveness of distance learning and the effective ways of assessing distance education programmes (Wolcott \& Betts, 1999). This paper also examines programme evaluation and assessment procedures not only to assess what and to what extent students have learned, but also to investigate how the quality of education has improved quality of life. Distance education has generated public interest to dispel the notion that, "traditional or regular" system of education is not the only learning environment in the development of human capital. By grassroots participation, distance learning opportunity is taken to almost door steps of learners.

In Ghana, about 55 per cent of students who participate in distance learning are from the rural settings. They are placed at designated centres that are closer and convenient to them. Indeed these centres have accounted and articulated the popularity of the programmes.

In addressing the institutional framework, one cannot skip the parameters and themes that address quality. The key metrics and strategies are based on institutional visions, missions, goals, objectives, outcomes and measures. The learning environment in some cases however is underpinned by problems associated with the successful implementation of the programme. This may revolve around financial commitments of students and the institutions, assessment procedures and quality of course tutors. Other important aspects may include infrastructural facilities, materials and equipment, welfare of students and efficiency in management.

The university of Cape Coast in Ghana has the largest students' population of over 40,000 (CoDE Report, 2018). The University of Cape Coast Distance Programme offers undergraduate and post graduate programmes in many disciplines such as the Sciences, Education studies, Social Sciences and Humanities, Business Education, Agriculture and Home Economics, and Languages. The 
courses are well structured with competent lecturers and course tutors as facilitators for the programme. Learning technology using the ICT mode is also applied for students in Ghana and abroad.

The inquiry from several observations is looking into the learning environment, precisely how students participate in lessons, materials used for the study, delivery of lessons and assessment procedures, thus, from face to face to writing of quizzes and examinations, and also evaluation. The study is guided by research questions.

\section{Research Questions}

Three research questions are posed in this investigation to provide accurate answers.

1) To what extent do teaching and learning reflect Distance Education mode of assessment?

2) What is the relationship between learning objectives and learning outcomes?

3) What are the challenges of assessment procedures?

\section{Significance of the Study}

The study hopes to provide substantive knowledge to all stakeholders in education including the outside world about distance learning and its numerous advantages. The key stakeholders include; the policy makers, institutions or organizations, administrators, students, parents and NGOs.

Work will serve as reference source to policy implementers, institutions, academics, academicians and personnel of the programme toward effective management and best practices.

Work hopes to reveal the appropriate methods and strategies in mounting programmes through the appropriate understanding of parameters used to achieve learning objectives and learning outcomes.

The study is a platform for awareness creation and potential benefits for audience in both academia and non-academic environment. Hence, it is a channel to disseminate information about the creation of human capital and the comparative advantages in the quality life.

\section{Review of Related Literature}

The relevant literature provides information on; what is distance learning? Perspectives of distance education and challenges of the distance education programme.

\section{What is Distance Learning?}

Distance education can be traced to the nineteenth century in England and continental Europe when colleges used postal services for providing education by means of correspondence (Phipps \& Merisotis 1999; Ponzurick, Russo, \& Logar, 2000; Sherry, 1996; Wernet, Olliges \& Delicath, 2000).

Distance learning has types such as distance education, e-learning, and online learning in which the main elements include the physical separation of teachers and students during instruction and the use of various technologies or course tutors to facilitate student-teacher communication (Cavanaugh, 2001). Distance 
learning has traditionally focused on students from diverse backgrounds including all forms of workers, the aged and those not working (Kwao, 2018). Presently, distance learning has become an established part of the educational world with trends pointing to ongoing growth, human development and capacity building. Today, an increasing number of universities and accredited institutions provide distance learning opportunities. Innovative approach to learning in distance education has been categorized (Lave \& Wenger, 1991). These include: 1) Conferencing courses (video conferencing), 2) Computer based training (CBT), 3) Print based courses, 4) Pre-recorded audio courses (tapes and podcasts), 5) Radio broadcast course and 6) Online course using management systems. At the University of Cape Coast in Ghana, the most used system is the Print based courses which largely provide the widest coverage for all programmes.

\section{Perspectives of Distance Education in Ghana}

The model used in Ghana is that students attend series of lectures at designated distance learning centres nationwide and then move onto main or centralized university campuses to attend "face to face", revise lectures, write quizzes and examinations while regular students are sometimes on vacation. Another model adopted is the franchised campus model, thus satellite campuses where each region has designated centres and where students undertake rigorous academic work, that is attend lectures and write their examinations.

The first model does not only give students the feel of campus life but also provides them access to the same facilities as regular students although over a limited time, that is only within a specific time frame. This approach sometimes is cost-effective to employers or management. Where employers would have to grant paid or unpaid study leave, they can now enjoy the benefits and services of its staff while they acquire the necessary training and skills for improved service delivery. One unique feature of distance education is that the mode of teaching has continuous loop throughout the year.

Various assessment matrices, assessment activities and assessment frequencies however must reflect the following (Rossi \& Wright, 1977).

1) Institutional Mission Statement

2) Accreditation

3) Summary of Departmental Assessment

4) Budget Review (monetary and fiscal policy)

5) Students' needs and Satisfactory Assessment

6) Distance Education Orientations, Matriculation and Graduation

7) Students' Profile Study. Students' Assessment Records

8) Students' Learning and Course Assessment Techniques

9) Review of Learning Resources

10) Course Evaluation 10 Course Development Review

11) Instructional Technology Assessment

12) Faculty/College Evaluation Survey

13) Needs Analysis for Training and 
14) Site visits by Accreditation Teams.

To add up is Monitoring and Supervision of Face to Face, Teacher Made Test (TMT) and Evaluation procedures on students' performance. Need for delivery of lessons and written materials are part of the provisions (modules/textbooks and test items of chief examiners, quizzes and examination papers).

In successive years, the University of Ghana and the University of Cape Coast started diploma programmes by distance in 2001/2002 in youth development work and basic education respectively (Hope \& Guiton, 2015). It is important to add that, other public and private universities also created spaces for distance education. By the end of 2013, nine accrediting institutions were offering distance programmes to their students (NAB, 2016). One emerging scenario is the duplication of courses by some of the institutions. Curriculum deficiency however maybe desynchronisation in some courses and programmes.

Trends and patterns in distance education in Ghana are very encouraging marks of the programme. The tertiary education sector in Ghana enrolled 374,017 students in both private and public institutions between 2008 and 2015 (NAB, 2015). Out of the total population of students, 362,402 students were enrolled in the public universities to suggest that public universities in the country contribute the largest number of students. Private distance enrolment over the review period was less than $1 \%(11,615)$ of the total enrolment of distance students (NAB, 2008). The wider gaps between public and private universities in distance education enrolment are issues that border around accreditation of courses, financial constraints, thus expensive nature of running courses, qualified personnel, infrastructural development, and efficiency in management. Other essential areas are supply of logistics to include reading materials and equipment.

A unique characteristic of the programme at the College of Distance Education, in the University of Cape Coast is that, it has a multi-purpose system which is highly integrated with the mainstream. Also, the college has a very strong equal opportunity approach attached to its philosophy. That is, the visions and missions of College of Distance Education are clearly defined and well conceptualized, and that has led to quality and access.

An emerging phenomenon is that distance education is creating more spaces in human resource development. Accordingly, it has improved access in tertiary education by enabling people who qualified but were unable to further their education, now doing so at their own pace. It has facilitated increased access in tertiary education. However this has progressively decreased the number of people seeking full time entry into institutions of higher learning (GOG, 2002). That is, it has raised some level of competitiveness in full time education and distance learning in Ghana. This analytical view may also be due to the comparative cost advantages and flexibility in distance learning (Kwao, 2018).

The traditional setting of distance education in Ghana may require more technology as curriculum expands correspondingly with increased access in enrol- 
ment figures. The compelling situations will require that Universities project online programme in a well-structured manner so as to integrate the system widely. This integrated dimension is another way of curriculum development toward keen participation of courses at the local and international levels. This will also call for international collaboration among lecturers and students.

The entire world is now placed on technology and therefore it is investment in technology that can enhance effective learning. Ghana in its strides to maintain quality education needs to move to another level of technology. This commitment is not only by the state but to all key stakeholders in education. Precisely, the role of the policy makers; the universities, public and private organizations, NGOs, philanthropists and parents are required to pull resources together for quality education in the country. The philosophy of education today is "cost sharing" and partnership. This is because government alone cannot supply all needs of the individual and society.

Their co-operation as stakeholders will help improve low level literacy rate, standard of living, mitigate poverty levels and drastic reduction in ignorance. What institutions need to put into consideration is student's needs and satisfaction arrangements which must be part of assessment and evaluation procedures. A pertinent question that may arise is whether there are adequate students' support services and apparatus to support distance learners. This may include advisory roles and career development and placement. It is obvious that distance learners have diverse needs such as family needs, business activities, and health issues.

Sometimes learning activities can be interrupted by births, illness, and loss of jobs, accidents, occupational mobility and perhaps death in the family which may require extension and appropriate records for such unfortunate ones. A reflective knowledge about students is very essential. Students' Affairs Section is required to have adequate data by getting to know students' socio-cultural backgrounds as soon as possible through the use of profiles that will help provide sufficient information to facilitators and administrators. One common mistake distance education instructors are likely to commit is by not giving enough for other activities (Sherry, 2002). Although this is a general statement, administrators including Students' Affairs Unit must also take accounts of students' welfare. This indeed will establish positive relationships between the service providers and service users.

\section{Challenges of the Distance Education Programme}

Challenges in running the distance programme include the following:

1) Well-defined institutional mission, vision statements and core values may not be up to expectation. It appears, the implementation process of some policies does not reflect the practices, and hence this affects the quality of education.

2) Well defined programme to meet standards criteria of Accreditation Board may demand questions. The course content for certain programmes will need to be refined to meet international standards. 
3) There seems to be inadequate qualified staff for certain courses and in some cases unqualified staff to teach certain courses.

4) Financial commitments by institutions and students are inadequate. This is a major problem where most institutions require huge capital for running programmes, remuneration packages for academic staff and other workers, supply of logistics and equipment, and library facilities and laboratories. Students as well need funding opportunities since it is difficult for some to pay for fees and other responsibilities.

5) Lack/inadequate information technology hinder academic work. There seems to be lack and inadequate gadgets, such as projectors for learning and video conferencing materials for those on online programmes.

6) Students' support services as compared to the mainstream needs much improvement since there seems to be complaints on assessment records, welfare services and designated centres for learning and 7) State, community and NGO support for the programme perhaps is a missing link in the academic environment (Kwao, 2018). There seems to be no record for assisting institutions neither there is any package for needy students.

\section{Methodology}

The methodology is a mixed approach (Jacob, 1987) using the quantitative and qualitative paradigms to generate answers. It is to provide context based on participants' point of view and their direct experience (English \& English, 1958) on distance learning. The direct experience was what key actors of the study were deeply involved in and could use that information to provide appropriate and relevant answers to the research problem. This presented students, course tutors and course coordinators of the study as the main actors. The research design was a case study.

Population of the study comprised 30 course tutors and $503^{\text {rd }}$ year Diploma students who offered Diploma in Basic Education, and Diploma in Educational Psychology and 5 course coordinators. Census was the sampling procedure used for all course tutors while the purposive sampling technique was applied for all students and course coordinators. The semi-structured interview was employed as the main instrument for both students and course tutors, and focus group interview for 5 course coordinators. Tools for the quantitative analysis were by the use of pie charts, frequencies and percentages, and the chi-square for validation of results. The qualitative data was purely discursive using thematic approach for the focus group discussion which was a form of triangulation. This was by a concurrent analysis which involved research question 3.

\section{Discussion}

Results of findings first delved into the biographical characteristics of participants followed by the main analysis generated from the three research questions.

Responses by Percentages 


\section{Pie Chart showing Programme of Study}

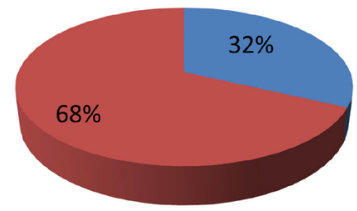

Pie Chart Showing working Experience

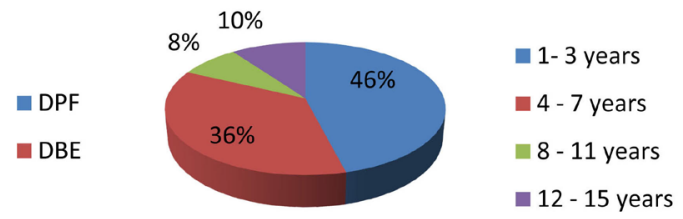

Pie Chart Showing Types of Occupation

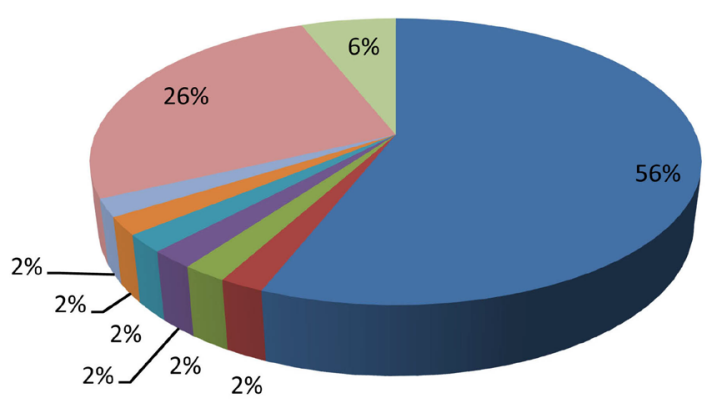

\author{
- Teacher \\ Nurse \\ - Carpentery \\ - Security \\ - Pharmacy Assistant \\ Catering \\ Bankers \\ N/A \\ Trader
}

At the two centres, results indicated the vast majority of students were those offering Diploma in Basic Education (68\%) which by far exceeded students offering Diploma in Educational Psychology (32\%). Diploma in Basic Education was the first professional teacher training programme introduced in distance learning (NAB, 2002). By the results, Diploma in Basic Education has gained more popularity than Diploma in Educational Psychology. However, spaces have been well created for all programmes.

The majority of respondents among students with work experience were within the age range between 1 to 3 years to suggest more youthful population in the programmes. Those within the working age limit of 12 to 15 years were mainly adults with longer years of work experience. The distance learning has indeed become part of the on-job training for categories of students who are workers. The non-teachers in the programme also have solid grounds for becoming professional teachers.

Occupational background of students had more teachers (68\%) dominating. This indicated that particular occupations are tied to specific programmes in some centres. The definition of terms provides understanding of items by analysis of the research questions.

Definition of Terms

1) Text Books refer to Modules

2) Other Books-Any Relevant Book and E-Library Materials

3) N/A-Not Applicable

Research Question 1: To what extend do teaching and learning reflect the distance mode of assessment? 


\begin{tabular}{|c|c|c|c|c|}
\hline \multirow{3}{*}{$\begin{array}{l}\text { Questions } \\
\text { What are the materials used to } \\
\text { facilitate students learning? }\end{array}$} & \multicolumn{4}{|c|}{ Responses by Students } \\
\hline & Text Books & Modules & N/A & \\
\hline & $14(28 \%)$ & $28(56 \%)$ & $8(16 \%)$ & \\
\hline \multirow{2}{*}{$\begin{array}{l}\text { How long do students } \\
\text { meet for a semester? }\end{array}$} & 6 weeks & 7weeks & 8weeks & 9 weeks \\
\hline & $22(44 \%)$ & $18(36 \%)$ & $6(12 \%)$ & $4(8 \%)$ \\
\hline \multirow{2}{*}{$\begin{array}{l}\text { What method is } \\
\text { applied in teaching? }\end{array}$} & lecture & Discussion & Others & N/A \\
\hline & $31(62 \%)$ & $14(28 \%)$ & $3(6 \%)$ & $2(4 \%)$ \\
\hline \multirow{2}{*}{$\begin{array}{l}\text { What is the mode } \\
\text { of assessment? }\end{array}$} & TMT & Quiz & End of semester & N/A \\
\hline & $8(16 \%)$ & $19(38 \%)$ & $21(42 \%)$ & $2(4 \%)$ \\
\hline $\begin{array}{l}\text { What do you suggest for the } \\
\text { mode of students' assessment? }\end{array}$ & $15(30 \%)$ & $14(28 \%)$ & $16(32 \%)$ & $5(10 \%)$ \\
\hline \multirow{2}{*}{$\begin{array}{l}\text { Are tutors satisfied with } \\
\text { the mode of assessment? }\end{array}$} & Yes & No & N/A & \\
\hline & $44(88 \%)$ & $2(4 \%)$ & $4(8 \%)$ & \\
\hline $\begin{array}{l}\text { How relevant and appropriate } \\
\text { are the materials for }\end{array}$ & Very Good & Good & Average & Below Ave. \\
\hline teaching and learning? & $14(28 \%)$ & $22(44 \%)$ & $6(12 \%)$ & $8(16 \%)$ \\
\hline How do you rate your teachers? & $30(60 \%)$ & $16(32 \%)$ & $3(6 \%)$ & $1(2 \%)$ \\
\hline
\end{tabular}

The key issues addressed materials that facilitate learning. The realization was that, apart from the use of modules (56\%), students preferred the use of other books (28\%) for learning. That also depicted students' reliance on other sources of information. It also implied that reliance on many sources of information is relevant for students than the use of only modules.

Another revelation was that, lecture method (62\%) dominated the lesson delivery. According to Kwao, 2018, lesson delivery must be integrated with the use of appropriate teaching methods. Davis \& Dykman (2008) opined that lesson delivery at the tertiary or university level is mainly integrated method of teaching and not lecture. There is the need to apply integrated approach to teaching instead of the lecture method where students will not be able to internalize adequate information.

The response (30\%) claimed that Teacher Made Test (TMT) should be factored into continuous assessment scores. From indications, two major assessment procedures satisfy the criteria. The procedure used the raw scores of quizzes $(40 \%)$ and end of semester examination as $60 \%$.The true picture from the data showed a missing link between the formative and summative assessment. It appeared that students' assessment was one short examination (quizzes and semester examination) which suggested summative mode of assessment. One of the criteria for assessment is fairness (Hope \& Guiton, 2015). Therefore students seemed not to be treated fairly since the continuous assessment component is not clearly defined. Ambiguities in assessment procedures may lead to poor performance or mass failures (Hope \& Caruth, 2013). This in the inquiry is a key issue yet to be resolved.

In validating the responses, the significant levels using the chi-square proved 
that null hypothesis was rejected for most items to mean both students and course tutors' responses were appealing. The responses when validated however indicated the TMT (Teacher Made Test) as unpleasant for students. The realization was that, TMT as a component of continuous assessment scores was not used by the University. Therefore, null hypothesis was accepted, thus, TMT not reflecting assessment result has become a big issue. This realization is purely an academic issue. The analysis of items for validation has been explained further.

Hypothesis of research question 1. Validation (Testing the significant differences of the questions). Are they equally appealing?

What Extend do Teaching and Learning Reflect the Distance Mode of Assessment

\begin{tabular}{|c|c|c|c|c|c|}
\hline \multirow{2}{*}{ Questions } & \multicolumn{5}{|c|}{ Responses by Validation } \\
\hline & Mode & Median & Chi-sq & $\mathrm{df}$ & $P$-value \\
\hline $\begin{array}{l}\text { What are the materials used to facilitate students' } \\
\text { learning? }\end{array}$ & Modules & & 12.640 & 2 & 0.002 \\
\hline How long do students meet for a semester? & 6 weeks & & 18.300 & 3 & 0.000 \\
\hline What method is applied in teaching? & Lecture & & 43.600 & 3 & 0.000 \\
\hline What is the mode of assessment? & Exams & & 19.600 & 3 & 0.000 \\
\hline $\begin{array}{l}\text { What do you suggest for the mode of students } \\
\text { assessment? }\end{array}$ & Exams & & 6.160 & 3 & 0.104 \\
\hline Are tutors satisfied with the mode of assessment? & Yes & & 67.360 & 2 & 0.000 \\
\hline $\begin{array}{l}\text { How relevant and appropriate are the materials } \\
\text { for teaching and learning? }\end{array}$ & & Very Good & 12.400 & 3 & 0.006 \\
\hline How do you rate your teachers? & & Very Good & 43.280 & 3 & 0.000 \\
\hline
\end{tabular}

The analyses of responses showed perfect correlation between percentage mean scores and the validation when the chi-square was employed. So far, claims were positive responses except the Teacher Made Test which assumed a negative response to suggest unfair situation on the part of students.

Research Question 2: What is the Relationship between Learning Objectives and Learning Outcomes

\begin{tabular}{|c|c|c|c|c|}
\hline \multirow[b]{2}{*}{ Questions } & \multicolumn{4}{|c|}{ Responses by Students } \\
\hline & Excellent & Very Good & Good & $\begin{array}{l}\text { Below } \\
\text { Average }\end{array}$ \\
\hline $\begin{array}{l}\text { How do the learning } \\
\text { objectives meet the lessons taught? }\end{array}$ & $3(6 \%)$ & $13(26 \%)$ & $26(52 \%)$ & $8(16 \%)$ \\
\hline $\begin{array}{l}\text { How appropriate is the content } \\
\text { and learning objectives? }\end{array}$ & $5(5 \%)$ & $17(34 \%)$ & $21(42 \%)$ & $7(14 \%)$ \\
\hline \multirow[t]{2}{*}{$\begin{array}{l}\text { What is your view about } \\
\text { what learnt and written papers? }\end{array}$} & $2(4 \%)$ & $26(52 \%)$ & $20(40 \%)$ & $2(4 \%)$ \\
\hline & Yes & No & N/A & \\
\hline Are the test items and content appropriate? & $42(84 \%)$ & $3(6 \%)$ & $5(10 \%)$ & \\
\hline Do all sessions reflect the test items? & $40(80 \%)$ & $7(14 \%)$ & $3(6 \%)$ & \\
\hline Are some of the questions out of context? & $9(18 \%)$ & $38(76 \%)$ & $3(6 \%)$ & \\
\hline Are you satisfied with the mode of assessment? & $40(80 \%)$ & $4(8 \%)$ & $6(12 \%)$ & \\
\hline
\end{tabular}


From the scores, there was positive correlation throughout the responses to imply that quality of the programme has met learning outcomes. The table provided indicated validation of results for research question 2 .

Hypothesis of research question. Validation (Testing the significant levels of the questions). Are they equally appealing?

What is the Relationship between Learning Objectives and Learning Outcome?

\begin{tabular}{|c|c|c|c|c|c|}
\hline \multirow{2}{*}{ Questions } & \multicolumn{5}{|c|}{ Responses by validation } \\
\hline & Mode & Median & Chi-sq & df & $P$-value \\
\hline How do the learning objectives meet the lesson taught? & & Good & 39.400 & 3 & 0.000 \\
\hline How appropriate is the content and learning objectives? & & Good & 28.000 & 3 & 0.000 \\
\hline $\begin{array}{l}\text { What is your view about what learnt and } \\
\text { written papers? }\end{array}$ & & Very Good & 9.680 & 3 & 0.021 \\
\hline Are the test items and content appropriate? & Yes & & 57.880 & 2 & 0.000 \\
\hline Do all sessions reflect the test items? & Yes & & 49.480 & 2 & 0.000 \\
\hline Are some of the questions out of context? & No & & 42.040 & 2 & 0.000 \\
\hline Are you satisfied with the mode of assessment? & Yes & & 62.680 & 2 & 0.000 \\
\hline
\end{tabular}

The $P$-value indicated that there was correlation between learning objectives and learning outcomes. Validation of results rejected the null hypothesis to suggest universality in responses. Learning outcomes were highly appealing and that was a form of motivation to students and course tutors. Achieving learning outcomes measure great successes (Piaget, 1983). Students' goals and aspirations in distance learning are therefore determined by the quality of teaching, learning objectives, and learning outcomes. The results provided evidence of good quality assurance procedures at the distance learning centres.

Research Question 3: What are the Challenges of Assessment?

\begin{tabular}{|c|c|c|c|c|}
\hline \multirow[b]{2}{*}{ Questions } & \multicolumn{4}{|c|}{ Responses by Students } \\
\hline & $\begin{array}{l}\text { Very } \\
\text { Good }\end{array}$ & Good & $\mathrm{Bad}$ & $\mathrm{N} / \mathrm{A}$ \\
\hline \multirow[t]{2}{*}{ How do you feel when using the model? } & $11(22 \%)$ & $25(50 \%)$ & $7(14 \%)$ & $7(14 \%)$ \\
\hline & Yes & No & N/A & \\
\hline $\begin{array}{l}\text { Are you comfortable } \\
\text { with the assessment procedure? }\end{array}$ & $37(74 \%)$ & $6(12 \%)$ & $7(14 \%)$ & \\
\hline $\begin{array}{l}\text { Are you satisfied with the content } \\
\text { and questions set for examination? }\end{array}$ & $36(72 \%)$ & $4(8 \%)$ & $10(20 \%)$ & \\
\hline Are you proud of the programme? & $41(82 \%)$ & $3(6 \%)$ & $6(12 \%)$ & \\
\hline $\begin{array}{l}\text { What are the things } \\
\text { that challenge teaching and learning? }\end{array}$ & $4(8 \%)$ & TMT $36(72 \%)$ & $3(6 \%)$ & $5(10 \%) \quad 2(4 \%)$ \\
\hline
\end{tabular}

From the analysis, the vast majority of students were satisfied with the content 
and assessment procedures in distance learning. The major issue raised was the Teacher Made Test (TMT) which is not part of their continuous assessment. This indeed is repetitive and emerging challenge.

Hypothesis of research question. Validation (Testing the significant levels of the questions). Are they equally appealing?

What are the Challenges of Assessment?

\begin{tabular}{|c|c|c|c|c|c|}
\hline \multirow{2}{*}{ Questions } & \multicolumn{5}{|c|}{ Responses by validation } \\
\hline & Mode & Median & Chi-sq & df & $P$-value \\
\hline How do you feel when using the model? & & Good & 17.520 & 3 & 0.001 \\
\hline Are you comfortable with the assessment procedure? & Yes & & 37.240 & 2 & 0.000 \\
\hline $\begin{array}{l}\text { Are you satisfied with the content } \\
\text { and questions set for examination? }\end{array}$ & Yes & & 34.720 & 2 & 0.000 \\
\hline Are you proud of the programme? & Yes & & 53.560 & 2 & 0.000 \\
\hline $\begin{array}{l}\text { What are the things that } \\
\text { challenge teaching and learning? }\end{array}$ & $\begin{array}{l}\text { No } \\
\text { (TMT) }\end{array}$ & & 85.000 & 4 & 0.100 \\
\hline
\end{tabular}

The responses by validation rejected the null hypothesis to indicate that students' claims are true reflections of quality structural arrangements and content validity. However, the validation of result accepted the null hypothesis with an indication that students were not happy about the rejection of Teacher Made Test (TMT) in the programme. This sounds like a deficiency in the assessment component, specifically weightings placed on formative and summative assessments.

\section{Biographical Representation of Course Tutors}

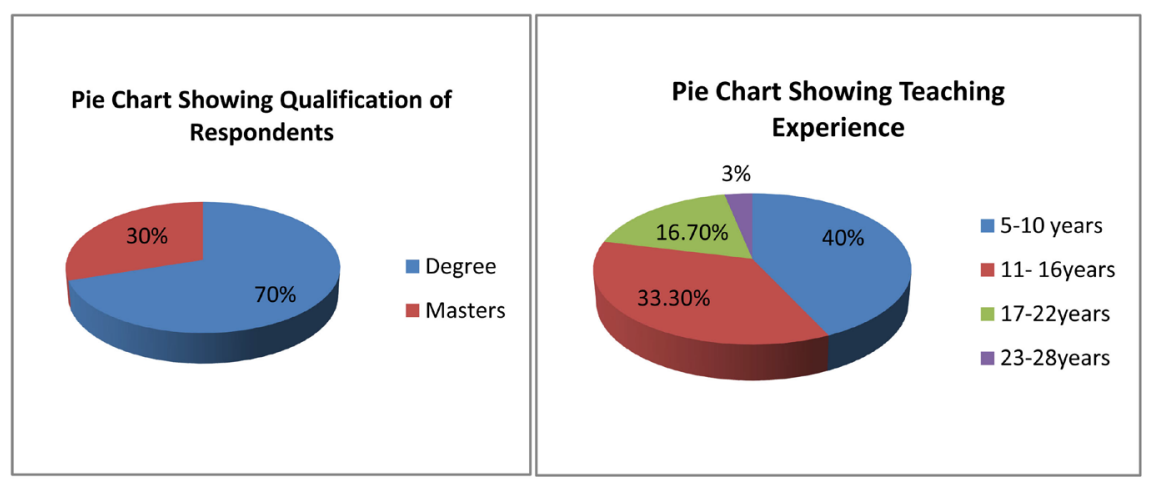

The biographical representation from the two centres indicated that most course tutors were first degree holders, some yet to obtain their Master's degree. This has the implication that any upgrading of programmes and courses would rather require tutors with at least Master's degree. Centres are required to have the best quality of tutors to draw correlation between academic competence and effective lesson delivery (Kwao, 2018). This also calls for standard criteria for selection of course tutors at various levels. 
What Extent do teaching and learning reflect the distance mode of Assessment?

\begin{tabular}{|c|c|c|c|c|c|}
\hline \multirow[b]{2}{*}{ Questions } & \multicolumn{5}{|c|}{ Responses by Course Tutors } \\
\hline & Modules & $\begin{array}{l}\text { Audio } \\
\text { Visual }\end{array}$ & Text Books & Other Books & \\
\hline \multirow[t]{2}{*}{$\begin{array}{l}\text { What are the materials used to } \\
\text { facilitate students learning? }\end{array}$} & $20(66.7 \%)$ & $3(10 \%)$ & $2(6.7 \%)$ & $5(16.7 \%)$ & \\
\hline & 6weeks & 7weeks & 8weeks & 9weeks & \\
\hline \multirow[t]{2}{*}{$\begin{array}{l}\text { How long do students meet } \\
\text { for a semester? }\end{array}$} & $25(83.3 \%)$ & $2(6.7 \%)$ & $1(3.3 \%)$ & $2(6.7 \%)$ & \\
\hline & Lectures & Discussion & Demonstration & Activity & Others \\
\hline \multirow[t]{2}{*}{$\begin{array}{l}\text { What method do you apply } \\
\text { in teaching? }\end{array}$} & $14(46.7 \%)$ & $7(23.3 \%)$ & $3(10 \%)$ & $4(13.3 \%)$ & $2(6.7 \%$ \\
\hline & TMT & Quizes & Exams & Assignment & \\
\hline \multirow[t]{2}{*}{$\begin{array}{l}\text { What is the mode of } \\
\text { assessment? }\end{array}$} & $5(16.7 \%)$ & $11(36.7 \%)$ & $12(40 \%)$ & $2(6.7 \%)$ & \\
\hline & Yes & No & N/A & & \\
\hline \multirow[t]{2}{*}{$\begin{array}{l}\text { Are tutors satisfied with the } \\
\text { mode of assessment? }\end{array}$} & $25(83.3 \%)$ & $3(10 \%)$ & $2(2.7 \%)$ & & \\
\hline & Very Good & Good & Satisfactory & $\mathrm{Bad}$ & \\
\hline \multirow{2}{*}{$\begin{array}{l}\text { How relevant and appropriate } \\
\text { are the materials for teaching } \\
\text { and learning? }\end{array}$} & $17(56.7 \%)$ & $10(33.3 \%)$ & $3(10 \%)$ & & \\
\hline & TMT & Quizes & Exams & Others & \\
\hline $\begin{array}{l}\text { What do you suggest for the } \\
\text { mode of students' assessments? }\end{array}$ & $3(10 \%)$ & $6(20 \%)$ & $18(60 \%)$ & $3(10 \%)$ & \\
\hline
\end{tabular}

The analysis provided evidence of null hypothesis being rejected. Respondents had a strong feeling that teaching reflects learning outcomes. Except that most tutors used the lecture method (46.7\%) of teaching. The tutors claimed that continuous assessment marks for students is (40\%) and examination is always $60 \%$ but the 10\% marks for Teacher Made Test is ignored. According to the course tutors, TMT as assessment procedure therefore has no significance. Amissing link is the fairness in continuous assessment procedures which the majority of course tutors claimed as a bias situation. Assessment must accurately reflect the range of expected outcomes of students (Green, 1978). The comparative analysis (responses from students and course tutors) showed that continuous assessment as formative evaluation procedure must be clearly defined as done in the mainstream.

Hypothesis of research question. Validation (Testing the significant levels of the questions). Are they equally appealing?

What Extent do teaching and learning reflect the distance mode of Assessment? 


\begin{tabular}{|c|c|c|c|c|c|}
\hline \multirow{2}{*}{ Questions } & \multicolumn{5}{|c|}{ Responses by Validation } \\
\hline & Mode & Median & Chi-square & $\mathrm{df}$ & $P$-value \\
\hline $\begin{array}{l}\text { What are the materials used to facilitate } \\
\text { students learning? }\end{array}$ & Modules & & 28.400 & 3 & 0.000 \\
\hline How long do students meet for a semester? & 6 weeks & & 54.533 & 3 & 0.000 \\
\hline What method do you apply in teaching? & Lecture & & 15.667 & 4 & 0.004 \\
\hline What is the mode of assessment & Exams & & 9.200 & 3 & 0.027 \\
\hline $\begin{array}{l}\text { Are tutors satisfied with the } \\
\text { mode of assessment? }\end{array}$ & Yes & & 33.800 & 2 & 0.000 \\
\hline $\begin{array}{l}\text { How relevant and appropriate are the } \\
\text { materials for teaching and learning? }\end{array}$ & Very Good & & 9.800 & 2 & 0.007 \\
\hline $\begin{array}{l}\text { What do you suggest for the mode of } \\
\text { students' assessments? }\end{array}$ & Exams & & 20.400 & 3 & 0.000 \\
\hline
\end{tabular}

It emerged from the validation that modules are the main sources of information for students. It also revealed that the lecture method was the most used for lesson delivery. More so, assessments were through examination (quizzes and end of semester exams).

What is the Relationship between Learning Objectives and Content?

\begin{tabular}{|c|c|c|c|c|}
\hline \multirow{2}{*}{ Questions } & \multicolumn{4}{|c|}{ Responses by Course Tutors } \\
\hline & Very Good & Good & Satisfactory & N/A \\
\hline $\begin{array}{l}\text { How do the learning objectives meet } \\
\text { the lesson taught? }\end{array}$ & $10(33.3 \%)$ & $15(50 \%)$ & $2(6.7 \%)$ & $3(10 \%)$ \\
\hline \multirow[t]{2}{*}{$\begin{array}{l}\text { How appropriate is the content and } \\
\text { he learning objectives? }\end{array}$} & $14(46.7 \%)$ & $11(36.7 \%)$ & $3(10 \%)$ & $2(6.7 \%$ \\
\hline & Yes & No & N/A & \\
\hline Are the test items and content appropriate? & $27(90 \%)$ & $3(10 \%)$ & & \\
\hline Do all sessions reflect the test items? & $22(73.3 \%)$ & $5(16.7 \%)$ & $3(10 \%)$ & \\
\hline Are some of the questions set are out of context? & $4(13.3 \%)$ & $24(80 \%)$ & $2(6.7 \%)$ & \\
\hline \multirow[t]{2}{*}{ Are you satisfied with the mode of assessment? } & $26(86.7 \%)$ & $4(13.3 \%)$ & & \\
\hline & TMT & Textbook & N/A & \\
\hline $\begin{array}{l}\text { Suggest any method or strategy that } \\
\text { can enhance effective teaching and learning }\end{array}$ & $25(83 \%)$ & $4(13)$ & $1(3)$ & \\
\hline
\end{tabular}

The analysis of course tutors also came out with a perfect correlation in responses implying that there is significant relationship between learning objectives and learning outcomes. Except that tutors claimed, Teacher Made Test has absolutely been ignored. The issue perhaps may have cumulative and adverse effects on students' performance.

Hypothesis of research question. Validation (Testing the significant levels of the research questions). Are they equally appealing?

What is the Relationship between Learning Objectives and Content? 


\begin{tabular}{|c|c|c|c|c|c|}
\hline \multirow{2}{*}{ Questions } & \multicolumn{5}{|c|}{ Responses by Validation } \\
\hline & Mode & Median & Chi-square & df & $P$-value \\
\hline $\begin{array}{l}\text { How do the learning objectives meet } \\
\text { the lessons taught? }\end{array}$ & & Good & 15.067 & 3 & 0.002 \\
\hline $\begin{array}{l}\text { How appropriate is the content and the } \\
\text { learning objectives? }\end{array}$ & & Very Good & 14.000 & 3 & 0.003 \\
\hline Are the test items and content appropriate? & Yes & & 19.200 & 1 & 0.000 \\
\hline Do all sessions reflect the test items? & Yes & & 21.800 & 2 & 0.000 \\
\hline $\begin{array}{l}\text { Are some of the questions set } \\
\text { out of context? }\end{array}$ & No & & 29.600 & 2 & 0.000 \\
\hline $\begin{array}{l}\text { Are you satisfied with the mode } \\
\text { of assessment? }\end{array}$ & Yes & & 16.133 & 1 & 0.000 \\
\hline $\begin{array}{l}\text { Suggest any method or strategy that } \\
\text { can enhance effective teaching } \\
\text { and learning TMT }\end{array}$ & Provision of & & 20.667 & 3 & 0.000 \\
\hline
\end{tabular}

The validation showed strong agreement in course tutors' assertion. That is, null hypothesis was rejected to mean total acceptance of learning objectives and learning outcomes. The validation however accepted the null hypothesis to reflect claims made against Teacher Made Test (TMT).

What are the Challenges of Assessment Procedures?

\begin{tabular}{|c|c|c|c|c|}
\hline \multirow{2}{*}{ Questions } & \multicolumn{4}{|c|}{ Responses by Course Tutors } \\
\hline & Yes & No & N/A & \\
\hline \multirow[t]{2}{*}{$\begin{array}{l}\text { Are you comfortable with the assessment } \\
\text { procedures? }\end{array}$} & $24(80 \%)$ & $4(13.3 \%)$ & $2(6.7 \%)$ & \\
\hline & Very Good & Good & satisfactory & $\mathrm{Bad}$ \\
\hline \multirow[t]{2}{*}{ How do you rate the teaching module? } & $19(63.3 \%)$ & $7(23.3 \%)$ & $4(13.3 \%)$ & \\
\hline & $\begin{array}{l}\text { Lack of } \\
\text { TLM's }\end{array}$ & $\begin{array}{c}\text { Poor } \\
\text { Methodology }\end{array}$ & $\begin{array}{c}\text { Lack of } \\
\text { Infrastructure }\end{array}$ & $\begin{array}{l}\text { Behaviours } \\
\text { of students }\end{array}$ \\
\hline \multirow[t]{2}{*}{$\begin{array}{l}\text { What are the things that challenge } \\
\text { teaching and learning? }\end{array}$} & $20(66.7 \%)$ & $4(13.3 \%)$ & $\mathrm{N} / \mathrm{A}$ & $6(20 \%)$ \\
\hline & Yes & No & $\mathrm{N} / \mathrm{A}$ & \\
\hline Are you proud of the programme? & $26(86.7 \%)$ & $2(6.7 \%)$ & $2(6.7 \%)$ & \\
\hline $\begin{array}{l}\text { Are you satisfied with the content and } \\
\text { questions? }\end{array}$ & $27(90 \%)$ & $2(6.7 \%)$ & $1(3.3 \%)$ & \\
\hline
\end{tabular}

In spite of the fact that students and course tutors were against non-compliance of Teacher Made Test (TMT), they commended the quality of assessments.

Hypothesis of research question. Validation (Testing the significant levels of the question). Are they equally appealing?

What are the Challenges of Assessment Procedures? 


\begin{tabular}{|c|c|c|c|c|c|}
\hline \multirow{2}{*}{ Questions } & \multicolumn{5}{|c|}{ Responses by Validation } \\
\hline & Mode & Median & Chi-sq & $\mathrm{df}$ & $P$-value \\
\hline $\begin{array}{l}\text { Are you comfortable with the } \\
\text { assessment procedures? }\end{array}$ & Yes & & 29.600 & 2 & 0.00 \\
\hline How do you rate the teaching module? & & Very Good & 12.600 & 2 & 0.002 \\
\hline $\begin{array}{l}\text { What are the things that challenge } \\
\text { teaching and learning? }\end{array}$ & Lack of TLM's & & 15.200 & 2 & 0.001 \\
\hline Are you proud of the programme? & Yes & & 38.400 & 2 & 0.00 \\
\hline $\begin{array}{l}\text { Are you satisfied with the content } \\
\text { and questions? }\end{array}$ & Yes & & 43.400 & 2 & 0.000 \\
\hline
\end{tabular}

The validation on challenges indicated universality in responses. The views presented a picture to mean that the University of Cape Coast distance education programme is on course.

\section{Interview: Focus Group Discussion}

This aspect of the analysis was by focus group discussion conducted for 5 course coordinators which also served as a form of triangulation.

Question 1. What are the materials used to facilitate learning?

We depend mainly on the modules supplied to students and no other textbook is used, although, some of the books still need to be revised." This was a universal response. According to the 5respondents, material quality is very good but requires revision in some cases. Are you sure you use only the module? Yes, this is what we are saying. The universal responses implied restriction in the use of only modules. The modules according to respondents are the only prescribed books. Students must be allowed to discover more facts and ideas from many sources of information and that increases their intellectual reasoning and problem solving techniques (Halsey, 1972). The need to use many sources of information by students at the tertiary level is very necessary.

Question 2. What method (s) do you apply in teaching?

Mostly, we apply the lecture method, pass commentaries with little discussion. Why do you choose lecture method to dominate the lesson? All the respondents replied,

It is not our fault because we need to finish the sections within time frame and also make sure we have a wider coverage. This seemed to be poor strategy. Kwao, 2018 suggested an integrated approach to lesson delivery and appropriate methods of teaching distance education. It seemed, lesson delivery needed to be strategized and monitored.

Question 3. Do your students capture everything?

Sometimes they complain since some sections are not well explained and also some questions occasionally are lifted from other sections without the knowledge of students during quizzes and exams." These are issues raised on content and construct validity to suggest that evaluation of reading and assessment ma- 
terials, and also moderation are necessary.

Question 4.What do you do with Teacher Made Test (TMT)? All the respondents replied,

Aaaaa, we play our part to ensure that the procedures are followed, so whether UCC uses it or not our duty is to provide them with assessment results on Teacher Made Test." Accordingly, determination of TMT by course tutors is compulsory but not implemented.

Does TMT reflect students' marks?

No... no. no, they don't because they do not use it and we think that is not fair, thus that is part of their continuous assessment. The universality in response reflected evidence adduced when quantitative data was generated. The system in which the quality of a student's work is judged by various pieces of work during a course by tutors is one of the best ways and not by one final exam only (Messick, 1994). From the respondents, we fear the "Macho man". Who is the Macho man and why that description? We fear to talk so that we are not black mailed. This is an assertion from the course tutors. From the structural arrangements and responses so far, UCC has an opened climate and therefore tutors could as well suggest continuous assessment procedures. Matters relating to continuous assessment scores however might call for measurement and evaluation discourse.

\section{Conclusion}

The two paradigms employed in the investigation revealed essential issues for policy implementation in distance education at the two centres which perhaps might reflect activities in other centres of the University of Cape Coast. The realization in the inquiry was that, there was high quality assurance procedures put in place. However, the structural arrangement appeared to have been underpinned by reliance on the module as main textbook and the unstructured way of lesson delivery which used to be mostly by lecture method. One debate which was a universal response using the two paradigms was the use of continuous assessment. This universality stimulated new thinking as to whether Teacher Made Test (TMT) is a genuine claim alleged by both course tutors and students. The complaints address the issue of fairness and justification. These indeed are matters relating to the implementation policies of the distance education programme.

\section{Recommendations}

The study discovered critical issues for redress.

1) The need for a well-defined continuous assessment component in distance learning is very essential. It is recommended that Teacher Made Test (TMT) which is part of students' continuous assessment should be part of the formative assessment. The quizzes organized as one shot examination by the University must have the appropriate weighting to include TMT otherwise assessment procedure will only be characterized by summative evaluation. 
2) The methods for lesson delivery should be modified. It is recommended that modern teaching and learning strategies are effectively adopted to enhance the quality of teaching.

3) The modules as main textbooks and reading materials should be extended to other material sources. Tertiary education requires reading materials from many sources so as to widen the horizon of students' learning and also as a way of stimulating their critical thinking.

4) Monitoring and evaluation are essential components in distance education. It is recommended that teaching and learning, and assessment procedures are effectively monitored for improved outcomes and best practices.

\section{Conflicts of Interest}

The author declares no conflicts of interest regarding the publication of this paper.

\section{References}

Cavanaugh, C. S. (2001). The Effectiveness of Interactive Distance Education Technologies in K-12 Learning: A Meta-Analysis. International Journal of Educational Telecommunications, 7, 73-88.

CoDE Report (2018). Annual Report on Distance Education. Ghana: University of Cape Coast.

Davis, C. K., \& Dykeman, C. A. (2008). Online Education Forum: Part Two-Teaching Online.

English, H. D., \& English, H. C. (1958). A Comprehensive Dictionary of Psychological and Psychoanalytic Terms. London: Longman.

GOG (2002). University of Cape Coast Education Report on Distance Learning. Accra, Ghana.

Green, B. (1978). In Defence of Measurement. American Psychologist, 33, 664-670. https://doi.org/10.1037/0003-066X.33.7.664

Halsey, A. H. (Ed.) (1972). Educational Priority: Vol. 1: I. E. P. A. Problems and Policies. London: HMSO.

Hope, A., \& Caruth, G. D. (2013). Distance Education in the United States: From Correspondence Courses to the Internet. Turkish Online Journal of Distance Education, 14, 141-149.

Hope, A., \& Guiton, P. (2015). Strategies for Suitable Open Distance Learning, Vol. 6. New York: Routledge /Falmer Press.

Jacob, E. (1987). Qualitative Research Traditions: A Review. Review of Educational Research, 57, 1-50. https://doi.org/10.3102/00346543057001001

Kwao, A. (2018). International Conference Paper. Distance Education at the Grassroots and Assessment Procedures. Ghana: University of Cape Coast.

Lave, \& Wenger, E. (1991). Situated Learning: Legitimate Peripheral Participation. New York: Cambridge University Press. https://doi.org/10.1017/CBO9780511815355

Messick, S. (1994). In R. K. Linn (Ed.), The Interplay of Evidence and Consequences ((3rd ed., pp. 13-103). New York, NY: Macmillan.

NAB (2008). Annual Report on Tertiary Education. Accra: NAB. 
NAB (2015). Ensuring Quality Standards in Tertiary Education in Ghana. Accra: NAB.

NAB (2016). Distance Learning Institution. Accra: NAB.

Phipps, R., \& Merisotis, J. (1999). What's the Difference? A Review of Contemporary Research on the Effectiveness of Distance Education in Higher Education. The Institute for Higher Education Policy.

Piaget, J. (1983). Piaget's Theory. In P. Mussen (Ed.), Handbook of Child Psychology (4th ed., Vol. 1). New York: Wiley.

Ponzurick, T., France, K. R., \& Logar, C. (2000). Delivering Graduate Marketing Education: An Analysis of Face to Face versus Distance Education. Journal of Marketing Education, 22, 180-187. https://doi.org/10.1177/0273475300223002

Rossi, L., \& Wright, S. (1977). Evaluation Research; an Assessment of Theory, Practice, and Politics. Evaluation Quarterly, 1, 5-52. https://doi.org/10.1177/0193841X7700100102

Wolcott, L. L., \& Betts, K. S. (1999). What's in It for Me? Incentives for Faculty Participation in Distance Education. Journal of Distance Education, 14, 34-39. 